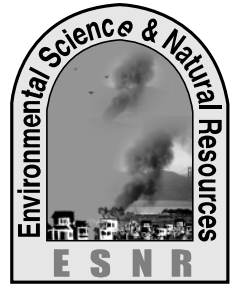

\title{
Effect of BAU-Biofungicide and Plant Extracts on Seedling Vigour of Maize
}

\author{
M. Debnath, A. Sultana and A. Q. M. B. Rashid
}

Seed Pathology Center, Bangladesh Agricultural University, Mymensingh

\begin{abstract}
An experiment was conducted in Seed Pathology Center, Bangladesh Agricultural University, Mymensingh to determine the efficacy of biocontrol means (BAU-Biofungicide, Garlic extract and Neem extract) and vigour index of seedling for controlling the seedborne fungal diseases of maize. In laboratory experiment, the prevalence of seed-borne fungi associated with maize cultivar cv. BARI Bhutta - 6 were investigated by blotter method. The identified fungi species were A. niger, A. flavus, Fusarium sp., P. oxalicum, C. lunata and R. stolonifer. The test materials were treated with BAU-Biofungicide @ 2.5\% of seed weight, neem extract @ 1:2 w/v and 1:3 w/v and garlic extract@1:2 w/v and 1:3 w/v to control the pathogens. Significantly, the highest germination (87.\%) and the lowest incidence of pathogen $(4 \%)$ was recorded in BAU-Biofungicide treated seed The maize seeds treated by BAU- Biofungicide also show the higher vigour index (2856) followed by neem extract (1:2) treated seed (2621) after germination.
\end{abstract}

Key ward: Biofungicide, Germination, Maize, Pathogens

\section{Introduction}

Maize (Zea mays L.) is one of the most important cereal crops in the world and ranks third next to wheat and rice (Aldrich et al., 1975). From the recent past, it has a good potential as a cereal crop due to its low cost of production, wide adaptability and diversified use in Bangladesh.

Maize suffers from 28 diseases in which 11 are seedborne in nature (Fakir, 2001). Among the diseases, seed rot ( $F$. moniliforme, $F$. oxysporum, Penicillium spp.), seedling blight (Aspergillus spp., Penicillium spp.), Bipolaris leaf spot (B. maydis), Curvularia leaf spot $(C$. lunata) etc. are important. Incidence of the seed borne pathogen cause germination failure as well as reduces the seedling vigour which ultimately reduces the yield. Control of the seedborne fungal pathogen by chemical fungicides is costly and hazardous for the environment. Therefore, the present piece of work was undertaken to reduce the prevalence of the seedborne pathogen associated with the maize seeds and to enhance the seedling vigor.

\section{Materials and Methods}

\section{Seed health test}

The widely cultivated maize seed variety BARI Bhutta - 6 was collected from BADC of Mymensingh, Dinajpur, Madupur, Rangpur and Gazipur. The seed samples were tested by standard blotter method (ISTA, 2001) in Seed Pathology
Center, Bangladesh Agricultural University, Mymensingh.

\section{Biofungicides}

Biofungicides such as BAU-Biofungicide (Trichoderma based preparation), Garlic extract, Neem extract were collected from the Department of Plant Pathology, Bangladesh Agricultural University (BAU), Mymensingh.

\section{Seed treatment}

One hundred seeds from each test materials were treated with BAU-Biofungicide @ 2.5\% of seed weight (Naznin and Hossain, 2004), neem extract@ 1:2 w/v and 1:3 w/v and garlic extract @ 1:2 w/v and $1: 3 \mathrm{w} / \mathrm{v}$ (Rahman et al.,1999) to control the seed borne pathogen.

\section{Experimental design and treatments}

The experiment was designed following CRD having four replications and the following six treatments

$\mathrm{T}_{1}=$ Seed treatment with garlic extract @ 1:2 $\mathrm{w} / \mathrm{v}$

$\mathrm{T}_{2}=$ Seed treatment with garlic extract @ 1:3 $\mathrm{w} / \mathrm{v}$

$\mathrm{T}_{3}=$ Seed treatment with neem extract @ 1:2 $\mathrm{w} / \mathrm{v}$

$\mathrm{T}_{4}=$ Seed treatment with neem extract @ 1:3 $\mathrm{w} / \mathrm{v}$

$\mathrm{T}_{5}=$ Seed treatment with BAU-Biofungicide $\mathrm{T}_{0}=$ Control 


\section{Sowing of seeds and raising of seedling}

The seeds were sown@25 seeds per tray $\left(1.5 \times 1 \mathrm{ft}^{2}\right)$ in three rows at 2-3 cm depth. Plants were watered whenever necessary.

\section{Recording of data}

Data on germination failure and diseased seedling were recorded at 7, 10 and 20 days after sowing. For determining seedling vigour 3 seedlings per tray were carefully uprooted, cleaned with tap water. Then root length and shoot length were taken. Vigour index of seedling under different treatments were recorded following the formula of Baki and Anderson (1973) as shown below:

Vigour index $=($ Mean root length + mean shoot length) $\times$ germination percentage.

\section{Analysis of data}

The collected data were statistically analyzed and treatment means were compared following DMRT (Duncan's Multiple Range Test).

\section{Results and Discussion}

Prevalence of seedborne fungi associated with the maize seed samples

The seedborne fungal pathogen was recorded through blotter method. The prevalence of the pathogen were A. niger (19.25\%), A. flavus (9\%), Fusarium spp.(11.5\%), P. oxalicum (7.0\%), C. lunata (5\%) and $R$. stolonifer $(8.75 \%)$. In agreement with this result Fakir (2001) Bari and Alam (2004) reported the same.

Effect on vigour index of the seedling (Tray method) The effect of garlic extract $(1: 2,1: 3)$, neem extract $(1: 2,1: 3)$ and BAU-Biofungicide @ $2.5 \%$ on vigour index of maize cv. BARI Bhutta- 6 is shown in Fig. 1. The vigour index of seedling varied from 2856 to 1885 where the significantly lowest (1885) vigour index was recorded in control and the highest (2856) vigour index was recorded from the seeds treated with BAU-Biofungicide which was $51.51 \%$ higher over control. The least but similar vigour index was recorded in rest of the tested varieties.

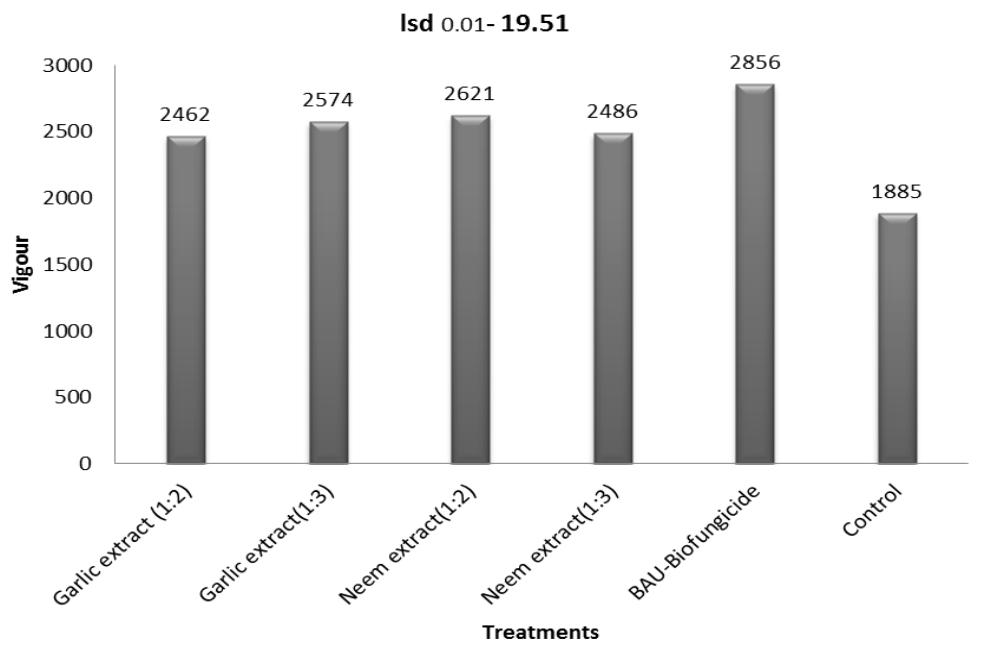

Fig. 1. Effect of seed treatment with Bio-fungicide on vigour index of maize seedling

In agreement with this study, Hossain and Sultana (2011) reported that the effect of BAU-Biofungicide has the great efficacy in controlling the seed and seedling diseases of other varieties of maize and increasing the seed germination, seedling vigour, plant stand and yield of maize.
The information is almost similar by Hossain and Naznin (2005) in case of vegetable seed. They found that seed treatment with BAU-Biofungicide resulted higher shoot length, root length and vigour index of summer mungbean varieties. Bhuiyan et al. (2006) also observed that seed treatment with BAUBiofungicide increased vigour index of the seedlings 
of 14 different winter vegetables up to $57.21 \%$ over the untreated control.

Shamsuzzaman et al. (2003) reported that Trichoderma harzianum (Biofungicide) treated seeds of sweet gourd resulted $95.62 \%$ higher vigour index over control (untreated). Gurjar et al. (2004) applied $T$. harzianum and T. viride and reported that these fungi exhibited increased seedling vigour of okra. El and Haikal (2007) applied T. harzianum and found that soil inoculation or grain coating with this fungus significantly increased the percentage of healthy seedlings as well as the length, fresh weight, dry weight and vigour index of seedlings.

\section{Conclusions}

From the present findings it is observed that the garlic extract, neem extract and the BAU-Biofugicide have the significant result in controlling seedborne fungal pathogen in maize and enhancing the seedling vigour. Among them, the BAU-Biofugicide has the strong potentiality for treating seeds of maize in controlling seed and seedling diseases. The seed treatment by BAU-Biofugicide may be widely practiced throughout the country.

\section{References}

Aldrich, S. R.; Scott, W. O. and Leng E. R. 1975. Modern corn production. $2^{\text {nd }}$ edition. United States of America. pp. 1-5.

Baki, A. and Anderson, 1973. Physiological and biological deterioration of seeds. In Seed Biology, Vol. II. Academic Press, New York. pp. 283-315.

Bari, M. A. and Alam, M. S. 2004. Major diseases of wheat and maize and their control. A Bengali Booklet published from the Division of Plant Pathology, BARI, Joydebpur, Gazipur 2: 12-16.

Bhuiyan, M. A. H. B.; Khokon, M. A. R. and Hossain , I. 2006. BAU-biofungicide in controlling seedling diseases of winter vegetables. Department of Plant Pathology, BAU, Mymensingh, Bangladesh. Bangladesh J. Plant Pathol., 22 (1/2): 1-5.

El, D. and Haikal, N. 2007. Role of biological control on some physiological aspects of Zea mays infected by Rhizoctonia solani. Department of Botany, Faculty of science, Cairo University, Giza Egypt. J. Appl. Sci., 6 (13): 2794-2798.
Fakir, G. A. 2001. List of seed borne diseases of important crops occurring in Bangladesh. Seed Pathol. Lab., Dept. Pl. Pathol., Bangladesh Agricultural University, Mymensingh. 9p.

FAO. 2009. Production Year Book. Food and Agriculture Organization, Rome, 53: 70-79.

Gurjar, K. L., Singh, S. D. and Rawal. P. 2004. Management of seed borne pathogens of okra with bio-agents. Plant Dis. Res. Ludhiana 19 (1): 44-46.

Hossain, I. and I. Sultana. 2011. Advantage of biocontrol means over chemicals in controlling seed and seedling diseases of maize. Int. J. Sustain. Agril. Tech., 7(5): 2127.

Hossain, I. and Naznin. M. H. A. 2005. BAUBiofungicide in controlling seedling diseases of some summer vegetables. BAU Res. Prog. 15:35.

ISTA (International Seed Testing Association). 2001. International Rules for Seed Testing. Rules Amendments. Seed Sci. and Tech., 29 (2): 1127.

Naznin, H. A. and Hossain, I. 2004. Effect of BAUBiofungicide on germination and seedling vigour of some summer vegetables. Bangladesh J. Seed Sci. \& Tech., 8 (1\&2): 85-90.

Rahman, G. M. M., Islam, M. R. and Wadud, M. A. 1999. Seed treatment with plant extracts and hot water, potential biophysical method of controlling seed-borne infection of wheat. Bangladesh J. Train. Dev., 12 (1-2): 185190.

Shamsuzzaman, S. M.; Islam, A. and Hossain, I. 2003. Production of Trichoderma conidia in agro-wastes. Bangladesh J. Environ. Sci., 9: $146-150$ 